\title{
Investigating the Essential Factors on Student Satisfaction: A Case of Albanian Private University
}

\author{
Lokman Coskun \\ Lecturer at Hëna e Plotë Bedër University of Tirana, Albania, \& A PhD candidate in European University of Tirana, Albania \\ E-mail-1: lokmancoskun@hotmail.com,E-mail-2: Icoskun@beder.edu.al
}

\section{Doi:10.5901/jesr.2014.v4n1p489}

\section{Abstract}

This study aims to examine an Albanian's private university in terms of student satisfaction; for student satisfaction in higher education is regarded an essential factor to obtain academic success in both educational arena and in higher education itself as well. In this study, a questionnaire was utilized in a private university in Albania to identify student satisfaction by considering six major factors. A '77-item' survey was conducted based on classroom-administration to identify which factors were prioritized by students for fruitful outcome. This study reveals that satisfaction model of education gives a ground to student-centered learning that causes effective teaching/learning, improves communication skills, and supportive learning environment. Institutional evaluation seems indispensable in the competitive educational environment. The results demonstrate that students giving more importance to academic staff, teaching, and relationships apart from technology, administration, and campus facilities. The results require that private educational institutions should take into consideration these 6 factors while allocating their existing resources for satisfying student expectation as well as competing with the challenging educational world. The findings of this study recommend the university administration to consider which factors to be essential one after another for providing a quality educational environment and with the aid of those factors; how to overcome this competitive educational world to obtain more academic achievement.

Keywords: Private Education, Student Satisfaction, Student Expectation, Service Quality, University Administration, Competitive, Educational Environment

\section{Introduction}

Higher educational institutions try to improve their teaching and physical facilities to attract more students to their respective universities in this challenging and competitive educational world. Without exception, nearly all countries have private higher educational institutions that are rapidly growing. On the other hand, they are improving service quality in order to maintain competitiveness in the sector.

Universities need to create 'a virtual circle' mentioned by Tang, et al., (2011) for the good of both students and universities themselves to develop mutual relationships and understanding in terms of sustainability of the institution and prospective investment.

Maslow's hierarchy of needs is used in this study. Especially, in terms of student satisfaction and motivation in higher education are supported by Maslow and that sheds lights to this questionnaire in a number of ways: Firstly, Maslow emphasizes the importance of safety, as it is observed that safety is an essential factor to attain goal, for it is related to environment (campus facility). Secondly, belongingness and love play an important role for friendship (relationship) in higher education. Thirdly, Esteem is required because of achievement and confidence (teaching, administration). Fourthly, self-actualization enables morality, creativity and problem solving (teaching, academic staff). Fifthly, physiological needs (campus and canteen) are met by the facilities of university environment.

The study involves six factors by considering the needs of teaching, academic staff, relationships, technology, administration and physical facilities as requirements in order to pin down any actual or perceived gaps between student satisfactions and expectations of the service offered. Secondly, another aim of this paper is to demonstrate how logical and holistic point of view for university administration to figure out quality service improvement, so that they can prioritize service quality dimensions and balance service quality gaps

Figuring out student satisfaction and identifying physical \& other factors and also improving service quality, and also teaching will contribute too much to educational institutions. After knowing student expectations; practical contributions will influence the level of student satisfaction as well as academic performance. For that reason, it is more beneficial to focus on what the students ask from their respective university. 
In satisfaction model by Cheng, et al., 2002, the performance of the educational institution can meet the needs and expectations of students, academic staff, administration, parents, members of university and alumni. In a university, the uppermost customers are the students and this higher education should know the importance of meeting students' needs and expectations.

The following pages include initially a literature review in term of understanding the issue of student satisfaction from the researchers' point of view. Because the existing researches give a broad context to this specific issue and help to understand the relationships between results, method, and methodology for collecting data.

After this part, the next part will be on research method that is a survey questionnaire to collect data for the study. This is a combination of quantitative and qualitative data collection.

Later on, the study will reveal that initially teaching staff, teaching, and technology are considered as preferences by university administration for better student satisfaction in the competitive higher education.

After this part, the study will discuss the finding with six different factors. In the study, satisfaction model is regarded important to understand existing service quality overall and to maintain expected service quality in competitive higher education.

Lastly, a conclusion will be drawn from the study. As a result, being responsive to the needs and expectations of the students creates a supportive environment and that situation not only encourages students but also increases a high level engagement between the students and academic staff.

\section{Literature Reviews}

Higher educational environments are the places to serve students, moreover, educational services are received by those students and they are the direct recipients of the higher education thereby. Students' perception regarding service quality enables an aspect to understand students' needs. Positive and negative comments of the students are helpful for identifying the required needs to satisfy students.

Students have a significant role to identify student satisfaction and they have a say in providing faultfinding feedback. One emphasizes that student satisfaction is described proportional to the students' perceived value concerning their educational institutions and experiences (Doris, et al., 2009). To satisfy students, Astin (1993) speaks of the significant effects of campuses in relation with the curriculum, the institution, and various educational experiences.

In particular, as Cooper, (2007) says that students are regarded as 'buyers' and institutions as 'sellers' alike in education. From that point of view, all courses and programs are needed to be assessed and meet the requirements of the respective students for better evaluation.

The following factors such as: campus facilities, technology, teaching, academic staff, relationships and administration of this survey are compatible with the suggestion of Cunningham, (2007), as he says that one is satisfied with an activity or object when his or her needs are met. If the effectiveness of institution in terms of educational performance is prioritized and also due importance is given to satisfy the needs of the students, as a result, students are motivated to perform better performance.

Further, According to (Zeithaml, Parasuraman \& Berry), one of the factors of SERVQUAL scale is Tangibles that are related to Physical facilities, equipment and appearance of personnel. In this regard, (Wiele, A. van der \& Iwaarden, J.D. van, 2002) emphasizes that the factors in the tangibles are as follows; 'up-to-date equipment', 'physical facilities and materials are visually appealing'.

For that reason, it is indispensable for universities to renew themselves visually, which is taken into consideration as amendments in physical facilities, since students opt for the universities that are up to date standard in term of appearance. But Munawar, et al., (2011), says that "tangibles are the physical appearance of the educational institution is not a matter of consideration for students." But, in this study, SERVQUAL scale model does not seem compatible with this study and not used to evaluate student satisfaction.

Not only physical appearance is considered essential for satisfaction but also other matters in higher education. Shahin, (2006) expresses how essential to know that customer expectations are properly understood and measured and that, from the customers' perspective, any gaps in service quality are identified. Astin, (1993) adds that university students foster less materialistic ideas and more idealistic ideas during the study years. That's why, the obtained data and information help university administrations how to close service quality gap and enable them to focus on scarce sources of the universities to make faultfinding decisions regarding universities.

Even though, it becomes critical to universities to identify their own lacking parts, but they benefit from the questionnaire thoroughly and prepare themselves up to date standard accordingly. Thus, strong academic performance 
can be acquired through giving preference to a research to identify existing facilities and in this regard, Cooper, (2007) also suggests that doing research brings about flexible approach to academic regulations. Munawar, et al., (2011), says that student satisfaction means satisfaction of parents, and society.

If universities want to survive and be preferred by the respective students in this challenging, competitive world, they need to give preference to student satisfaction. This study hopes to obtain existing service quality in higher education, so that the educational institutions consider reflections of the students for the betterment of the education.

Kwek, et al,.(2010), emphasize that the proliferation of private universities and the emergence of dynamic market demand have drawn the attention of private university administrations to identify and evaluate the overall factors of service quality considering different educational model of quality. Step by step, this environment becomes competitive, and then the feedbacks from students seem either faultfinding or beneficial to the respective institution. According to Cheng, (1998), the education environment will face challenges stemming from economy, political life, and technology and also will be more demanding.

Meanwhile, keeping pace with the standards of education quality internationally becomes more difficult and also continuously improving and upgrading the level of education quality seems to be necessary. Stukalina, (2012) says that university administration can get their respective students' perspective about the quality of educational environment to make students participate in decision-making process, because university administration is likely to introduce improvements for prospective students. This approach seems to help too much for new strategies.

Mai, (2005) says that students have more freedom of choice in terms of higher education, for there is a convergence of international employment needs, technological advancement, and qualifications due to speedy information exchange.

Therefore, educational institutions become international arena for learning and those education providers try their best to recruit international students to compete with their counterparts. Audhesh, et al, (2009), says that universities seem to be business entities, and they compete for resources and students either in local or international arena. Stukalina, (2012), says that "Evaluation in education can be characterized as the organized collection and analysis of data to provide constructive feedback about different aspects of the educational environment, which is necessary to support decision-making within an educational institution".

Different education models are constructive and fruitful by dint of increasing service quality. Cheng, et al,. (1997) suggest seven models of education quality as follows; (1) satisfaction model; (2) goal and specification model; (3) absence of problems model; (4) resource-input model; (5) organizational learning model; (6) legitimacy model; and (7) process model.

In this study, the satisfaction models is utilized to measure students' satisfaction and expectations due to the importance of each factor and identify the fundamental dimensions of the satisfaction factors. According to Shahin, (2006), if service quality is considered to be improved, then it is essential to contact students regularly to assess and evaluate their service experiences. In order to identify student level of satisfaction, students' perceptions are needed for educational institutions.

Besides, Munawar, et al., (2011) says that "Positive perception about the quality of service offered leaves positive image in the mind of students which finally leads them towards higher level of satisfaction".

One of the aims in an educational institution is to satisfy students, for satisfied students are the sources of competitive edge. According to Cuseo, J. (2003), the second aim is that institutional efforts are reasonable to improve student satisfaction level in terms of monitoring student retention for degree completion.

Low, (2000) draws attention to three points such as attracting, satisfying and retaining due students are considered as preferences in providing quality service, because favorably allocating the sources of the institution will be fruitful.

Actually, to focus on student satisfaction can bring about student-centered learning, according to Lea, S. J., et al,. (2003), firstly, student-centered learning gives way to reliance upon active rather than passive learning, secondly, an emphasis on deep learning and understanding, thirdly, increased responsibility and accountability on the part of the student, fourthly, increased sense of autonomy in the learner, finally, an interdependence between teacher and learner. Fourthly, Stukalina, (2012), says that "There is a necessity to link the needs of the customer with service functions in the framework of creating a student-centered educational environment". Munawar, et al., (2011), also says that "Educational institutions should offer student's centered service and education".

Students-centered learning helps students with taking responsibility in learning process and its impact is being obserfed in academic performance which is prerequisite for the institution. Tang., et al,.(2011) emphasizes that at the university the students must take responsibility, because this will in turn give a scope to explore themselves, to identify 
their strengths and weaknesses, and so, university becomes a mini environment of working world to learn how to have relations with other people. Tang, et al,. (2011) adds that the quality higher education brings about creativity and independence in the students.

The satisfaction of powerful educational constituencies such as academic staff, students, administration will know the major criterion of educational quality. Accordingly, they can perform competent educational activities that can increase the satisfaction of educational constituencies. But, in this study, student satisfaction is prioritized and the questionnaire is prepared by considering the satisfaction model.

Kara, A. (2004) emphasizes the importance of student satisfaction, otherwise, dissatisfied students may not attend many courses or drop out of university completely. Besides, Audhesh K., et al, (2009), emphasizes the importance of student satisfaction and adds that if students are satisfied with education service, they are more likely to advise their respective university to others and in fact, become an advocate for that education institution.

Actually, academic performance of the institution is essential for survival, for that reason, academic satisfaction should be considered very important, since it positively affects learning. With the aid of the questionnaire, it will be possible to minimize the uncertainty that bothers both 'buyers' and 'sellers' (Cooper, 2007).

In this survey, service quality in terms of campus facilities, technology, teaching, academic staff, relationships and administration is being evaluated from the angle of students regarding student expectation and satisfaction which result in institutional performance. Stukalina, (2012) adds that in higher education, service quality evaluated through the student's perspective. Tang., et al,.(2011) further adds that if higher education providers insist to have quality service, they gradually enter into a 'virtual circle'. It means that they invest good facilities and resources, so students' satisfaction will be higher than before.

If the satisfaction of the students is higher, then the experience and feedback will be positive and constructive and those students will inform their friends to come to their respective university, as a result more and more students will come in that then provide more funds, thus universities reinvest in better facilities and resources.

Therefore, 'a virtual circle' can be created. Stukalina, (2012), postulates that administration of a higher institution should make sure that their respective institution possesses ample and appropriate resources necessary for providing sustainable learning process. Those resources indicate either the material or intellectual capacity of the institution, but the intellectual capital is essential and main valuable assets of educational community.

In fact, this is the way to increase student loyalty towards university and to give a feeling and understanding that they have the power to affect change in their university. So, if these six factors are delivered effectively, the level of student satisfaction will increase in higher educational institutions and also bring about fruitful results. For that reason, as Munawar, et al., (2011) reminds that "University administration should focus on the quality of service to increase the satisfaction level of students." Those satisfaction factors are explained in detail in following pages.

\subsection{Academic staff}

Stukalina, (2012) emphasizes that "students tend to agree with each other in their ratings of an instructor, and that they are at least moderately valid, in that student ratings of course quality correlate positively with other measures of teaching effectiveness".

\subsection{Teaching}

Teaching makes the difference in the lives of students; it will give some experiences, and enables the students to be creative. It brings about educational success and plays a very significant role for the future of the institution and it also depends on not only student efforts but also university administration.

\subsection{Relationships}

Students want an interaction with the teaching staff in an institution, if there is a convenient and conducive environment to learning. The more fruitful interaction with the teaching staff, the better learning and performance occur in the educational institution. As a matter of fact, students are not only in contact with teaching staff, but also with physical facilities of the environment.

Additionally, Munawar, et al., (2011) emphasizes the significance of relationships and says the continuous effort by the university can increase the satisfaction level of respective students in relation with quality service, eventually; 
university is regularly judged and compared to other educational institutions in terms of the level of satisfaction. Then, Audhesh K., et al, (2009) says that positive relations between administration and students can create a scope to identify learning conditions and also other internal conditions.

\subsection{Technology}

Technology increases the satisfaction of the students in educational environments, according to Doris, et al., (2009); if there are the experiences of technology difficulties or there is no access to sufficient technology and tools, satisfaction is likely to diminish.

Further, Stukalina, (2012) emphasizes that technology is an essential factor to establish an efficient system for internal communication in terms of transferring knowledge in educational institution.

\subsection{Administration}

Administration is responsible for supervision and maintenance of higher education and its constructive approaches can prevent many problems from happening. Stukalina (2012), says that in order to keep all lines of communication in the institution open, administration needs to collect data for understanding the situation where they are operating.

\subsection{Campus Facilities}

Campus facilities are necessary to satisfy students in terms of student retention, because, they spend most of their time there and influenced by the physical facilities. So, students attach importance to physical facilities except social facilities. Particularly, they have the right to demonstrate attitudes to the existing facilities and system.

As Cuseo, J. (2003) says, satisfied students are more enthusiastic and socially integrated or get involved in campus life, and those students feel that they are part of their respective campus community, and also are more likely to continue their graduation. Munawar, et al., (2011), says that "Higher their level of satisfaction greater would be the quality of students." and adds that "Level of satisfaction directly affects students' performance."

\section{Research Methodology}

The survey has the following questions to comprehend the issue well and this survey was conducted during the spring semester at a private university in Albania that is requesting anonymity. Both qualitative and quantitative approach was employed in this study. In the context of active learning environment, this study can be utilized to assess and measure perceived university satisfaction to acquire and validate an instrument.

The questionnaire was prepared for measuring the student satisfaction on university considering six-factors to acquire students' responses and identifying their approaches with respect to studying in higher education. The main aim is to identify and evaluate those factors which affect student satisfaction in private university environment.

The questionnaire requests the following information; (a) about their university experiences in relation with campus facilities, teaching, administration, social relationships, technology, and teaching staff, as a result, (b) how those factors provide satisfaction and meet future expectations from their respective university. A 342 return was received. The questionnaire has two sections separately in order to compare student views about university in general and in particular accordingly.

Regarding method, questionnaire is utilized. To collect data 500 questionnaires have been distributed to undergraduate students at a private university in spring semester in Albania. The following reasons enable to comprehend why this university was selected, because it is an international university that has students of 15 different nationalities and also expectations of the students of this university are higher and various in terms of quality service when compared to the other universities. Additionally, the name of the university was not mentioned due to confidentiality and anonymity and also the graduates of this university are planning to go abroad, for the medium of teaching language is English as Lingua Franca.

Just 342 questionnaires were accepted right. Out of that, 158 questionnaires were not accepted, hence, they were considered unusable, and they were incomplete, it was also considered that those respondents were either uninterested to cooperate or not amply serious with the survey.

Under 6 main factors, a 77-item survey questionnaire was used for students to evaluate the quality of service in 
higher education, before now it was developed by Laurie et al. (1994). Moreover, the survey was conducted in an objective manner through quantitative approach. A self-completion questionnaire was distributed and answered by the respondents.

SBSS statistics 20 version was utilized to obtain data, such as statistical analysis, factor analysis, and descriptive statistics, compare means, One-Way ANOVA, reliability analysis, frequencies and also crosstabs. As the demographic information: gender, nationality, department, and monthly income of the parents were requested in the questionnaire. This technique was used to collect data, because it is suitable for in depth data analysis and it organizes data in optimal manner and also this technique enhances the reliability of the data.

\subsection{Survey aims and objectives}

The main aim of this study is to identify and evaluate the factors that influence student satisfaction in the Albanian private educational environment. The research objectives are

to:

* check out the literature concerning student satisfaction to identify the factors on student satisfaction;

* evaluate the influence of each factor on student satisfaction and the importance and impact of each factor on students;

* identify the areas of service priority towards better allocation of resources;

- discuss the benefit of the study;

\subsection{Limitations}

In this research study, some limitations appeared as follows; firstly, the study is limited to a single university in Albania, that's why; in the future, comparative studies might be conducted for fruitful decision making process. Secondly, the survey questionnaire was done on the $50 \%$ of students of the university. Even though, it is enough to obtain a good response rate for a case study. But a higher response rate will give more accurate response and more details. Besides, this research study aims only satisfaction of students, but in relation with satisfaction, other studies should be conducted considering the view of parents, and society etc.

\section{Research Hypotheses}

- $\quad$ H1) Institutional performance is positively related to service quality.

- H2) Higher the level of student performance will be both higher the level of service quality and student satisfaction.

- H3) Students' perception of service quality might help for decision making process.

- H4) Experience of the students provides enormous contribution to the development of the university.

- H5) There is a positive relationship between the teaching/physical facilities and the students' perceived service quality.

- H6) Current students recommend their respective university to others if they are satisfied with service quality.

\section{Findings}

This study has reached the following findings.

Table 1 shows that first and foremost, students give more significance to academic staff of all, since the difference between mean values appears very close to each other as 4.65 to 4.61 in all variables regarding academic staff and there is a correlation amongst the mean scores regarding these five main variables in the scale.

On the contrary, the difference amongst the mean scores in other factors is quite different and not so close to each other. Secondly, students consider technology more important than other factors, as it is seen the difference between mean values such as 4.66 to 4.51 in the variables. Thirdly, they place emphasis on teaching, as it is understandable from the variables in the table 1 , such as from 4.49 to 4.2 in this evaluation. Fourthly, they give particular importance to campus facilities, since it is understood from mean values such as; 4.49 to 3.91 . Then fifthly, they attach importance to relationships with others, as it is clearly seen in mean values such as 4.26 to 3.92 hereby. Lastly, they consider administration important in higher education, and as such mean values between from 4.27 to 3.41 are observed in 
table1.

Furthermore, we examined meaningful relations between the following statements 'University should have professional professors, lecturers and supervisors', and demographic characteristic of three factors thorough one way ANOVA method (Table-3-B and Table-4-B). The result supports the idea that universities should give due importance to the professionalism and knowledge of the teaching staff for fruitful and successful outcome.

These results emphasize that the students who will work public/private sector are more motivated and satisfied with the flexibility in the courses and workloads. So, Table-7-A and Table-8-A demonstrate that university should give more importance to the flexibility of the courses and workloads after professionalism of the teaching staff, for the students find the flexible courses and workloads so useful and fruitful in terms of student satisfaction.

And also, we examined meaningful relations between the following statements 'Did University contribute something to your career plan?', and demographic characteristic of three factors thorough one way ANOVA method (Table-10-B). The result supports the idea that universities should maintain the existing overall facilities and consider improving itself for more student satisfaction due to competitive higher education in the world.

\section{Discussions}

Table 1: Scale Questions

\begin{tabular}{|c|c|c|c|c|}
\hline No. & General Perception & & & University Has....... \\
\hline \multicolumn{5}{|c|}{ Campus Facility } \\
\hline 1 & $\begin{array}{l}\text { Location and environment of Campus are important for } \\
\text { student }\end{array}$ & 4.28 & 3.34 & Campus environment and location are good \\
\hline 2 & Quality of campus facilities makes student satisfied & 4.07 & 3.81 & Campus facilities in term of quality are $\mathrm{OK}$ \\
\hline 3 & $\begin{array}{l}\text { Library resources are useful in terms of quality and } \\
\text { availability of university }\end{array}$ & 3.91 & 3.54 & $\begin{array}{l}\text { Library resources in terms of quality and availability are } \\
\text { use full }\end{array}$ \\
\hline 4 & Parking facilities should be spacious and comfortable & 4.06 & 3.62 & $\begin{array}{l}\text { Parking facilities in terms of space and availability are } \\
\text { comfortable }\end{array}$ \\
\hline 5 & When I am on campus, I would like to feel secure and safe & 4.49 & 3.91 & On campus, security and safety are sufficient \\
\hline \multicolumn{5}{|c|}{ Teaching } \\
\hline 1 & I should have flexibility of course and unit requirements & 4.2 & 3.68 & Flexible course and required units are available \\
\hline 2 & $\begin{array}{l}\text { The range and diversity of topics and units should be very } \\
\text { comprehensive }\end{array}$ & 4.2 & 3.65 & $\begin{array}{l}\text { Scope and diversity of topics and units are } \\
\text { comprehensive }\end{array}$ \\
\hline 3 & I should receive quality education from my university & 4.6 & 3.94 & Quality education is available at the university \\
\hline 4 & Workload and study demands are my first preferences & 4.11 & 3.78 & Workload and study requirements are sufficient \\
\hline 5 & $\begin{array}{l}\text { I should receive fruitful feedback related to assignments and } \\
\text { assessment }\end{array}$ & 4.25 & 3.7 & $\begin{array}{l}\text { Feedback related to assignments and assessment is } \\
\text { fruitful }\end{array}$ \\
\hline 6 & I always need the course that will provide job prospects & 4.49 & 3.61 & Job prospects are obtained from the courses \\
\hline \multicolumn{5}{|c|}{ Technology } \\
\hline 1 & Website of university is important for students. & 4.51 & 4.06 & Website of university is good \\
\hline 2 & I should always find computer availability of university & 4.42 & 3.45 & Computer availability of university is sufficient \\
\hline 3 & A university should have a very useful student email service. & 4.54 & 4.02 & Student email service of university is OK \\
\hline 4 & $\begin{array}{l}\text { At university, there should be computing and technology } \\
\text { services }\end{array}$ & 4.58 & 3.76 & $\begin{array}{l}\text { Computing and technology services of university are } \\
\text { good }\end{array}$ \\
\hline 5 & $\begin{array}{l}\text { On campus, internet access should be available and useful } \\
\text { for students }\end{array}$ & 4.66 & 3.37 & Internet access of university is available and useful \\
\hline \multicolumn{5}{|c|}{ Relationships } \\
\hline 1 & I should have opportunities to develop close friendships & 3.92 & 3.46 & $\begin{array}{l}\text { Opportunities of university for developing close } \\
\text { friendships are good }\end{array}$ \\
\hline 2 & $\begin{array}{l}\text { I should have chances to spend enjoyable time with other } \\
\text { people on campus }\end{array}$ & 4.05 & 3.35 & $\begin{array}{l}\text { Environment of campus to spend enjoyable time with } \\
\text { other people is OK }\end{array}$ \\
\hline 3 & I should have opportunities to make friends & 4.03 & 3.55 & $\begin{array}{l}\text { Opportunities of university to make friends are } \\
\text { available }\end{array}$ \\
\hline 4 & I should have chances to pursue my social interests & 4.19 & 3.38 & $\begin{array}{l}\text { Chances of university to pursue social interests are } \\
\text { good }\end{array}$ \\
\hline 5 & At this university, I should find a quality social life & 4.26 & 3.24 & Quality of social life at university is good. \\
\hline \multicolumn{5}{|c|}{ Academic Staff } \\
\hline
\end{tabular}




\begin{tabular}{|c|l|l|l|l|l|}
\hline 1 & $\begin{array}{l}\text { University should have professional professors, lecturers } \\
\text { and supervisors }\end{array}$ & 4.65 & 3.91 & $\begin{array}{l}\text { Professors, lecturers and supervisors of university are } \\
\text { professional }\end{array}$ \\
\hline 2 & $\begin{array}{l}\text { There should be teaching ability of professors, lecturers and } \\
\text { supervisors. }\end{array}$ & 4.64 & 3.74 & $\begin{array}{l}\text { Professors, lecturers and supervisors of university } \\
\text { have teaching ability }\end{array}$ \\
\hline 3 & $\begin{array}{l}\text { Quality professors, lecturers and supervisors should be at } \\
\text { university. }\end{array}$ & 4.61 & 3.81 & $\begin{array}{l}\text { Professors, lecturers and supervisors of university are } \\
\text { of good quality }\end{array}$ \\
\hline 4 & $\begin{array}{l}\text { Level of knowledge of professors, lecturers and supervisors } \\
\text { should be sufficient }\end{array}$ & 4.61 & 3.95 & $\begin{array}{l}\text { Professors, lecturers and supervisors have sufficient } \\
\text { level of knowledge }\end{array}$ \\
\hline 5 & The teaching staff of university should be always available & 4.61 & 3.78 & The availability of teaching staff of university is good \\
\hline 1 & Administration \\
\hline 2 & $\begin{array}{l}\text { Administration staff should be flexible and approachable in } \\
\text { meeting my needs }\end{array}$ & 4.418 & 3.07 & Financial cost of study of university is OK \\
\hline 3 & $\begin{array}{l}\text { The services from administration staff should be supportive } \\
\text { for students }\end{array}$ & 4.35 & 3.43 & $\begin{array}{l}\text { Administration staff of university is flexible and } \\
\text { approachable }\end{array}$ \\
\hline 4 & $\begin{array}{l}\text { Services from administration staff are good and } \\
\text { university }\end{array}$ \\
\hline 5 & I should be satisfied with the scheduling of lectures \\
\hline
\end{tabular}
It was adapted from Laurie et al. (1994)

*1-5 scale means are used

Private universities play a vital role in improving education in Albania and contribute to a remarkable economic and educational growth to integrate with Europe. A survey is developed and conducted in a private university in Tirana, for it is the main hub of education and the capital city of Albania. This paper has discussed the importance of student satisfaction and evaluation of it in higher education, since student's indirect participation in terms of decision-making needs to be assessed for sound and prospective decision in the competitive educational environment.

In the present analysis, Table 1 shows the mean scores on each of the five scales in relation with six factors in this study, as well as Cronbach's alpha was used for giving a measure of the internal consistency of each of the scales. To obtain mean scores on each of the scales, dependent variables were utilized and also for independent variables the gender and nationality were considered. But gender and nationality were not remarkably relevant to any of the scale scores.

Table 2: Future Career Expectation, Personal Information

\begin{tabular}{|c|c|c|c|}
\hline \multicolumn{4}{|c|}{ Total number of students that participated : 342} \\
\hline \multicolumn{2}{|r|}{ Future Career Expectation } & No. of students & Overall \% \\
\hline 1 & Students that will set up their own business, after graduating & 66 & 19.3 \\
\hline 2 & Students that will work in public or private sector, after graduating & 228 & 66.7 \\
\hline 3 & Students that will pursue their parents business, after graduating & 34 & 9.9 \\
\hline 1 & Planning to do post-graduation & 305 & 89.2 \\
\hline 2 & NOT planning to do post-graduation & 23 & 6.7 \\
\hline 1 & University meet the expectations in term of education & 286 & 83.6 \\
\hline 2 & University DIDN'T meet the expectations in term of education & 42 & 12.3 \\
\hline & Personal Information & No. of students & Overall \% \\
\hline 1 & Albanian Students & 300 & 87.7 \\
\hline
\end{tabular}

Regarding higher educational learning environment, above-mentioned results reflect the dimensions of students' perceptions and give the assessments that the preferences of the students are as follows successively; academic staff, technology, teaching, relationships, campus facilities, and administration. In table 2, most of the students of the university plan to do post-graduation, they are 89.2. This is quite too much and consists of 305 students out of 342 . It means the university prepares its respective students for life-long learning in the future. Additionally, 228 students out of 342 plan to work in public and private sector after graduation. It demonstrates that the university contributes too much for the development of the society in the future. From a practical point of view, we can say that even though there is a 
correlation among the variables in each factor, but it is a fact that we cannot express every variable is perfectly reliable.

\subsection{Descriptives-1}

University should have professional professors, lecturers and supervisors

Table-3-A

\begin{tabular}{|l|c|c|c|}
\hline & $\mathrm{N}$ & Mean & Std. Deviation \\
\hline I will set up my own business & 66 & 4.48 & .949 \\
\hline I will work in public service or private sector & 228 & 4.77 & .571 \\
\hline I will pursue my parents business & 34 & 4.32 & 1.147 \\
\hline NA & 14 & 4.36 & .842 \\
\hline \multicolumn{1}{|c|}{ Total } & 342 & 4.65 & .757 \\
\hline
\end{tabular}

\subsubsection{ANOVA}

University should have professional professors, lecturers and supervisor

Table-3-B

\begin{tabular}{|c|c|c|c|c|c|}
\hline & Sum of Squares & df & Mean Square & F & Sig. \\
\hline Between Groups & 10.006 & 3 & 3.335 & 6.084 & .000 \\
\hline Within Groups & 185.281 & 338 & .548 & & \\
\hline Total & 195.287 & 341 & & & \\
\hline
\end{tabular}

\subsection{Descriptives-2}

Level of knowledge of professors, lecturers and supervisors should be sufficient

Table-4-A

\begin{tabular}{|c|c|c|c|}
\hline & N & Mean & Std. Deviation \\
\hline I will set up my own business & 66 & 4.45 & .980 \\
\hline I will work in public service or private sector & 228 & 4.73 & .620 \\
\hline I will pursue my parents business & 34 & 4.32 & 1.036 \\
\hline NA & 14 & 4.21 & .975 \\
\hline Total & 342 & 4.61 & .779 \\
\hline
\end{tabular}

\subsubsection{ANOVA}

Level of knowledge of professors, lecturers and supervisors should be sufficient

Table-4-B

\begin{tabular}{|c|c|c|c|c|c|}
\hline & Sum of Squares & $\mathrm{df}$ & Mean Square & $\mathrm{F}$ & Sig. \\
\hline Between Groups & 9.750 & 3 & 3.250 & 5.568 & .001 \\
Within Groups & 197.302 & 338 & .584 & & \\
Total & 207.053 & 341 & & & \\
\hline
\end{tabular}

As it is seen in descriptive data-1 \& 2 and determined as Table-3-A, and Table-4-A concerning the academic staff, the mean value is higher for the students who will work in public service or private sector than the other two statements such as "I will pursue my parents business" and "I will set up my own business". It means that those students who will work in public/private sector want more professionalism and knowledge from their respective teaching staff.

\subsection{Descriptives-3}


A university should have a very useful student email service.

Table-5-A

\begin{tabular}{|l|c|c|c|}
\hline & N & Mean & Std. Deviation \\
\hline I will set up my own business & 66 & 4.45 & .807 \\
I will work in public service or private sector & 228 & 4.64 & .673 \\
I will pursue my parents business & 34 & 4.29 & .799 \\
NA & 14 & 4.00 & .784 \\
\multicolumn{1}{|c|}{ Total } & 342 & 4.54 & .732 \\
\hline
\end{tabular}

\subsubsection{ANOVA}

A university should have a very useful student email service.

Table-5-B

\begin{tabular}{|c|c|c|c|c|c|}
\hline & Sum of Squares & df & Mean Square & $\mathrm{F}$ & Sig. \\
\hline Between Groups & 8.719 & 3 & 2.906 & 5.639 & .001 \\
Within Groups & 174.208 & 338 & .515 & & \\
Total & 182.927 & 341 & & & \\
\hline
\end{tabular}

\subsection{Descriptives-4}

On campus, internet access should be available and useful for students

Table-6-A

\begin{tabular}{|l|c|c|c|}
\hline \multicolumn{1}{|l|}{} & $\mathrm{N}$ & Mean & Std. Deviation \\
\hline I will set up my own business & 66 & 4.59 & .744 \\
I will work in public service or private sector & 228 & 4.75 & .558 \\
I will pursue my parents business & 34 & 4.35 & .981 \\
NA & 14 & 4.21 & 1.311 \\
\multicolumn{1}{|c|}{ Total } & 342 & 4.66 & .704 \\
\hline
\end{tabular}

\subsubsection{ANOVA}

On campus, internet access should be available and useful for students

Table-6-B

\begin{tabular}{|c|c|c|c|c|c|}
\hline & Sum of Squares & $\mathrm{df}$ & Mean Square & $\mathrm{F}$ & Sig. \\
\hline Between Groups & 8.147 & 3 & 2.716 & 5.708 & .001 \\
Within Groups & 160.826 & 338 & .476 & & \\
Total & 168.974 & 341 & & & \\
\hline
\end{tabular}

As it is understood in descriptive data-3 \& 4 and indicated as Table-5-A and Table-6-A in relation with technology, the mean value is higher for the students who will work in public service or private sector than the other two statements. It means that those students who will work in public/private sector demand internet access and e-mail service from their respective university.

\subsection{Descriptives-5}

Workload and study demands are my first preferences

Table-7-A

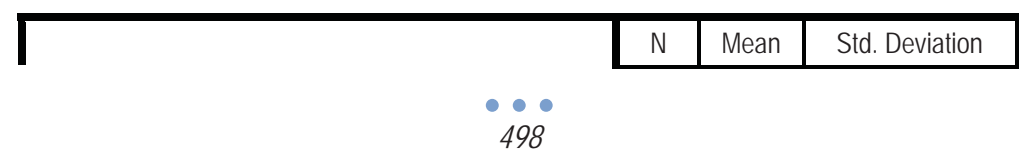




\begin{tabular}{|c|c|c|c|}
\hline I will set up my own business & 66 & 3.79 & 1.015 \\
I will work in public service or private sector & 228 & 4.23 & .856 \\
I will pursue my parents business & 34 & 4.03 & .834 \\
NA & 14 & 3.86 & .770 \\
Total & 342 & 4.11 & .898 \\
\hline
\end{tabular}

\subsubsection{ANOVA}

Workload and study demands are my first preferences

Table-7-B

\begin{tabular}{|c|c|c|c|c|c|}
\hline & Sum of Squares & $\mathrm{df}$ & Mean Square & $\mathrm{F}$ & Sig. \\
\hline Between Groups & 11.142 & 3 & 3.714 & 4.757 & .003 \\
Within Groups & 263.856 & 338 & .781 & & \\
Total & 274.997 & 341 & & & \\
\hline
\end{tabular}

\subsection{Descriptives-6}

I should have flexibility of course and unit requirements

Table-8-A

\begin{tabular}{|c|c|c|c|}
\hline & N & Mean & Std. Deviation \\
\hline I will set up my own business & 66 & 4.12 & .713 \\
I will work in public service or private sector & 228 & 4.28 & .801 \\
I will pursue my parents business & 34 & 4.18 & .936 \\
NA & 14 & 3.50 & 1.160 \\
Total & 342 & 4.20 & .828 \\
\hline
\end{tabular}

\subsubsection{ANOVA}

I should have flexibility of course and unit requirements

\section{Table-8-B}

\begin{tabular}{|l|l|l|l|l|l|}
\hline & Sum of Squares & df & Mean Square & F & Sig. \\
\hline Between Groups & 8.609 & 3 & 2.870 & 4.310 & .005 \\
Within Groups & 225.064 & 338 & 666 & & \\
Total & 233.673 & 341 & & & \\
\hline
\end{tabular}

According to descriptive data- 5 \& 6 and also determined as Table-7-A and Table-8-A, regarding 'teaching". It means that those students who will work in public/private sector want more flexibility in the courses and workload \& study demands from their respective teaching staff.

There is another meaningful finding regarding the students who will work in public/private sector, according to ANOVA results as demonstrated in Table-7-B and Table-8-B; beforehand the reference value is .005 , and .003, the mean value is between 4.28 and 4.23 for students who will choose public/private sector that is higher than the other values, such as: the value is 4.18 for the students who choose their own business or the value of parents business is 4.12.

\subsection{Descriptives-7}

At this university, I should find a quality social life

Table-9-A 


\begin{tabular}{|l|c|c|c|}
\hline I will set up my own business & 66 & 4.09 & 1.077 \\
I will work in public service or private sector & 228 & 4.34 & .810 \\
I will pursue my parents business & 34 & 4.26 & .864 \\
NA & 14 & 3.71 & 1.139 \\
\multicolumn{1}{c|}{ Total } & 342 & 4.26 & .895 \\
\hline
\end{tabular}

\subsubsection{ANOVA}

At this university, I should find a quality social life

Table-9-B

\begin{tabular}{|c|c|c|c|c|c|}
\hline & Sum of Squares & df & Mean Square & $\mathrm{F}$ & Sig. \\
\hline Between Groups & 7.432 & 3 & 2.477 & 3.149 & .025 \\
Within Groups & 265.925 & 338 & .787 & & \\
Total & 273.357 & 341 & & & \\
\hline
\end{tabular}

In accordance with descriptive data-7 and also written as Table-9-A, about "relationships". It is understood that those students who intend to work in public/private sector want more quality in social life from their respective higher institution.

\subsection{Descriptives-8}

Did University contribute something to your career plan?

Table-10-A

\begin{tabular}{|l|c|c|c|}
\hline \multicolumn{1}{|l|}{} & $\mathrm{N}$ & Mean & Std. Deviation \\
\hline I will set up my own business & 66 & 2.92 & 1.194 \\
I will work in public service or private sector & 228 & 3.02 & 1.165 \\
I will pursue my parents business & 34 & 3.06 & 1.013 \\
NA & 14 & 3.93 & 1.385 \\
\multicolumn{1}{|c|}{ Total } & 342 & 3.04 & 1.176 \\
\hline
\end{tabular}

\subsubsection{ANOVA}

Did University contribute something to your career plan?

Table-10-B

\begin{tabular}{|c|c|c|c|c|c|}
\hline & Sum of Squares & $\mathrm{df}$ & Mean Square & $\mathrm{F}$ & Sig. \\
\hline Between Groups & 12.065 & 3 & 4.022 & 2.959 & .032 \\
Within Groups & 459.362 & 338 & 1.359 & & \\
Total & 471.427 & 341 & & & \\
\hline
\end{tabular}

As it is observed in descriptive data-8 and determined as Table-10-A, concerning the contribution of the university to career plan, the mean value is higher for the students who wish to work in public service or private sector. It stands for that those students who wish to work in public/private sector are happy with the university in terms of their future career.

This study confirms the validity of these six factors and clarifies the importance of understanding student satisfaction by knowing existing problems and future developments of the institution. If this questionnaire is applied in a higher educational environment, it might give some strategies for university improvement and also a long term action plan to achieve educational goals.

In educational institution, essential service is mainly academic staff, teaching, and relations but other facilitate factors such as; technology, administration, and campus facilities which enhance the interaction and bring about the creative learning. Student interactions with academic staff, administration, campus facility, technology teaching, and campus social environment enable experience to students. This acquired experience might be negative and positive. To satisfy students with the existing service, it seems essential that firstly, provide the service then monitor that service for 
the good of gainfulness and satisfaction.

Stukalina (2012) adds that if educational institutions intend to be successful, they need to focus on their students' requirements and expectations, since the data they collected are the indicators of expectations, needs and wants of their students, and university administration should provide those efficiently not only for prospective outcomes but also student-centered approach in delivering their services.

Stukalina, (2012) also emphasizes that "the most important determinants of student satisfaction are the academic and pedagogic quality of teaching". That's why, firstly, university administration should give due importance to academic staff, teaching, and relations one by one and then the other factors such as; technology, administration, and campus facilities accordingly. The fact is that as Munawar, et al., (2011) emphasizes "Students don't rate institute on the basis of building and physical appearance but on the grounds of quality of education." Briefly, both students and university need to be convinced that they can be successful in the learning environment after mutual considerations and providing due orientation.

If so, a six-factor student satisfaction questionnaire may play an important role in the improvement of a methodology in respect of the assessment and evaluation of higher education.

The quality of the experiences that universities offer to their students in higher education would vary in different countries, but in the conditions of Albanian universities, these factors seem enough to identify student expectations associated with student satisfaction.

Student positive or negative attitudes towards university reveal the gap between satisfaction and expectation, essentially the result is the performance. This performance would be a mirror of the respective university among its competitors. This type of survey questionnaire might be "voice of students" (Stukalina, 2012).

Actually, identifying student satisfaction is very significant, because, the private universities are being compared in public. In particular, competitiveness in private educational environment in Albania to integrate with the worldwide university system makes this survey significant. Researchers are of the opinion that student satisfaction paves the way for competing with challenging educational world.

\section{Conclusion}

In this study, as implications and findings, this study urges the ways to perceive the world and to understand it better for offering sustainable expected service quality from the students. Higher educational institutions should focus on both quality education and quality improvement.

Moreover, they need to give ears to the comments and critical approaches of the students, so that they can strengthen their place in the competitive educational arena. In an operative word, the aim is to improve quality of education in higher education. We suggest that, "Student satisfaction, being the result of student interactions with the educational environment in the form of students' perceptions of the educational environment is an outcome of the expectations and experiences of the subject, study course, or study program as a requisite element of the integrated educational environment". Stukalina, (2012).

Even though, the findings of this survey cannot be generalized for all private higher education environments. But some various strategies such as satisfaction model is advised to University administrators to enhance and allocate the resources of the institutions to the improvement of the education quality which is proportional to the overall student expectation in relation with service quality.

University administration needs not to forget that as Stukalina, (2012) says "student satisfaction is regarded as a key product of higher education". For that reason, higher educational institution should be responsive to the expectations and needs of the students for better satisfaction. Eventually, as Munawar, et al., (2011) emphasizes "Greater the level of students' satisfaction, higher will be their motivation to put more efforts and they will produce better results."

Stukalina, (2012) supports that "satisfaction is supposed to be closely related to motivation - that is with the intention to continue their studies to obtain new knowledge". Thus, the sense of responsibility is spread among them (the students and academic staff) and allows logical reasoning which is necessary for competitive educational environment. Trying to meet students' needs will pave the way for student satisfaction, and then it will cause student motivation. Because motivation starts with unsatisfied needs.

The results can be used by the private higher educational institutions to develop better strategies owing to more competitive educational world and necessity of sustainable quality education.

\section{References}


Astin, A.W. (1993). What matters in college? Four critical years revisited. San Francisco: Jossey-Bass.

Audhesh K. Paswan PhD \& Gopala Ganesh PhD (2009): Higher Education Institutions: Satisfaction and Loyalty among International Students, Journal of Marketing for Higher Education, 19:1, 65-84

Cuseo, J. (2003). Academic Advisement and Student Retention: Empirical Connections and Systemic Interventions, Retrieved May 24, 2013.

http://www.nc-access.info/Advisement_Retention_Cuseo.pdf

Cheng, Y. C.. Tam, W. M., \& Tsui, K. T. (2002). New Conceptions of Teacher Effectiveness and Teacher Education in the New Century, Hong Kong Teachers' Centre Journal, Vol. 1, Spring 2002.

Cheng, Y,. (1998). The Pursuit of a New Knowledge Base for Teacher Education and Development in the New Century, Asia-Pacific Journal of Teacher Education \& Development, Vol. 1, No. 1, pp. 1-15.

Clewes, D. (2003), A Student-Centered Conceptual Model of Service Quality in Higher Education, Qual. High. Educ., Vol. 9, No. 1, pp. 69-85.

Cooper, P., (2007) Knowing your 'lemons': quality uncertainty in UK higher education, Quality in Higher Education, 13 (1), pp 19-29

Doris U. Bolliger \& Oksana Wasilik (2009): Factors influencing faculty satisfaction with online teaching and learning in higher education, Distance Education, 30:1, 103-116

Eyck, R., Tews, M., \& Ballester, J. M. (2009). Improved Medical Student Satisfaction and Test Performance With a Simulation-Based Emergency Medicine Curriculum: A Randomized Controlled Trial. Paper presented at the ACEP 2008 Research Forum, October 2008, Chicago, IL.

George B. Cunningham, (2007): Development of the PhysicalActivity Class Satisfaction Questionnaire (PACSQ), Measurement in Physical Education and Exercise Science, 11:3, 161-176

Harvey, L., Green, D. (1993). Defining Quality. Assessment and Evaluation in Higher Education. Vol. 18.

Jusoh, Ahmad (2004). Service quality in education management students' perspective. In: ASEMAL4 Conference, 2004, n/a.

Kara, A. (2004). Business Student Satisfaction, Intentions and Retention in Higher Education: An Empirical Investigation. MEQ, 03(Fall 2004), 1-15.

Kwek, C.L., Tan, H.P. and Lau, T.C. (2010), The Impact of Resource Input Model of Education Quality on the Overall Students' Perceived Service Quality, Canadian Social Science, Vol. 6 No. 2, pp. 125-144. [EBSCO, ABI/ProQuest, AMICUS, Gale] ISSN: $1712-8056$

Laurie A. Schreiner, Ph.D. and Stephanie L. Juillerat, Ph.D. (1994). Student Satisfaction Inventory, retrieved from

www.noellevitz.com/student-retention-solutions/satisfaction-priorities-assessments/student-satisfaction-inventory/samples, Cited date 20/01/2013

Mai, L. (2005). A comparative study between UK and US: The student satisfaction in higher education and its influential factors. Journal of Marketing Management, 21, 859-878.

Marsh, H.W. (1987). Students' evaluations of university teaching: research findings, methodological issues, and directions for future research. International journal of Educational Research, 11, pp. 253-388.

Maslow, A., (1943). A Theory of Motivation. Psychological Review, 50, pp 370-396.

Munawar khan, M., Ahmed, I. \& Musarrat Nawaz, m. (2011). Student's Perspective of Service Quality in Higher Learning Institutions; An evidence Based Approach, International Journal of Business and Social Science, 2(11), 159-160.

Northumbria Research Link. (2013, May 20 ). Evaluating business student satisfaction in the Malaysian private educational environment. Retrieved June 21, 2013, from Northumbria Research Link: http://nrl.northumbria.ac.uk/7991/

Parasuraman, A. Zeithaml, V.A. \& Berry, L.L. (1988). "SERVQUAL: a multi-item scale for measuring customer perceptions of service quality. Journal of Retailing, 64(1), 12-40.

Ramsden, Paul, (1991). A performance indicator of teaching quality in higher education: The Course Experience Questionnaire, Studies in Higher Education, 16: 2, $129-150$

Roberts, J., Gentry, D. \& Townsend, A. (2009). Student Perspectives: Evaluation a Higher Education. Administration Program. Journal of Case Studies in Education, 1-20

Shahin, A. (2006). SERVQUAL and model of service quality gaps: A framework for determining and prioritizing critical factors in delivering quality services. in: Partha Sarathy V. (Ed.). Service quality - An introduction (pp. 117-131). Andhra Pradesh: ICFAI University Press.

Tang S.F., \& Sufean Hussin, (2011). Quality in Higher Education: A Variety of Stakeholder Perspectives. International Journal of Social Science and Humanities, Vol. 1, No. 2, July 2011

Wiele, A. van der \& Iwaarden, J.D. van, 2002. A Study On The Applicability Of SERVQUAL Dimensions Of Web Sites, Research Paper ERS-2002-61-ORG.

Yin Cheong Cheng, Wai Ming Tam, (1997). Multi-models of quality in education, Quality Assurance in Education, Vol. 5 Iss: 1 , pp.22 31

Zeithaml, Parasuraman \& Berry, (1990). Delivering Quality Service; Balancing Customer Perceptions and Expectations, Free Press, 1990.

Zeithaml, V. A, Berry, L. L., Parasuraman, A. (1993), The Nature and Determinants of

Customer Expectations of Service, J. Acad. Mark. Sci., Vol. 21, No. 1, pp. 1-12.

Yulia Stukalina (2012): Addressing service quality issues in higher education: the educational environment evaluation from the students' 
perspective, Technological and Economic Development of Economy, 18:1, 84-98 